\title{
Agroforestry Systems and Their Contribution to Supplying Forest Products to Communities in the Chure Range, Central Nepal
}

\author{
Deepa Khadka ${ }^{1, *}$, Anisha Aryal ${ }^{2}$ D, Kishor Prasad Bhatta ${ }^{1} \mathbb{D}$, Bed Prakash Dhakal ${ }^{1}$ and Himlal Baral ${ }^{3,4}(\mathbb{D}$ \\ 1 Faculty of Forest Science and Forest Ecology, Georg-August-Universität, Busgenweg 5, \\ 37077 Goettingen, Germany; k.bhatta@stud.uni-goettingen.de (K.P.B.); \\ bed.dhakal@stud.uni-goettingen.de (B.P.D.) \\ 2 Faculty of Environmental Sciences, Technische Universität Dresden, 01737 Dresden, Germany; \\ anisha.aryal@mailbox.tu-dresden.de \\ 3 Center for International Forestry Research (CIFOR), Jalan CIFOR, Situ Gede, Bogor 16115, Indonesia; \\ h.baral@cgiar.org \\ 4 School of Ecosystem and Forest Sciences, University of Melbourne, Parkville, VIC 3010, Australia \\ * Correspondence: deepa.khadka@stud.uni-goettingen.de
}

Citation: Khadka, D.; Aryal, A.; Bhatta, K.P.; Dhakal, B.P.; Baral, H. Agroforestry Systems and Their Contribution to Supplying Forest Products to Communities in the Chure Range, Central Nepal. Forests 2021, 12, 358. https://doi.org/ $10.3390 /$ f12030358

Academic Editor: Julien Fortier

Received: 30 January 2021

Accepted: 15 March 2021

Published: 18 March 2021

Publisher's Note: MDPI stays neutral with regard to jurisdictional claims in published maps and institutional affiliations.

Copyright: (c) 2021 by the authors. Licensee MDPI, Basel, Switzerland. This article is an open access article distributed under the terms and conditions of the Creative Commons Attribution (CC BY) license (https:// creativecommons.org/licenses/by/ $4.0 /)$.

\begin{abstract}
Agroforestry (AF), an integration of agricultural and/or pastureland and trees, is a powerful tool for the maximization of profit from a small unit of land; however, it has been less well explored and recognized by existing policies. AF could be the best approach to conserving the fragile soils of Chure and to supplying subsistence needs to the local people. This study endeavored to understand how the adoption of various AF practices contributed to people's livelihoods in the Bakaiya rural municipality of Makawanpur District. To achieve this, 5 focus group discussions, 10 key informant interviews and 100 household surveys were conducted. These were analyzed using various statistical analysis tools: Kruskal-Wallis test, Games-Howell post hoc comparison test and Wilcoxon test. Thematic analysis was employed to understand the status and growth process of AF in the study area. Of three different AF systems used in the area, agri-silviculture was found to be the dominant form. Local people derived forest products, especially fuelwood, fodder and leaf litter from AF, where agri-silvi-pasture was most common. The three AF systems studied here were in turn compared with community forestry (CF), which is a participatory forest management system overseen by the community. People derived almost $75 \%$ of fuelwood from $C F$, whereas in the case of fodder and leaf litter, contributions from CF and AF were almost equal. Despite the potentiality of AF in fulfilling the demands of local people, promotional and development activities were lacking. This study recommends a strong collaboration of local people and concerned stakeholders for the promotion and technical facilitation of AF systems.
\end{abstract}

Keywords: agroforestry systems; Chure conservation; livelihood; community forestry

\section{Introduction}

Improving the well-being of poor people along with the sustainable management of natural resources are global targets under the United Nation's sustainable development goals [1]. The exploitation of the world's natural resources is occurring at such an alarming rate that the livelihoods of poor people could become even more precarious in the near future, especially in the global south [2,3]. Analogous to other developing countries, Nepal is facing severe pressure on its natural resources, as more than $80 \%$ of the population depend on them [4,5]. Food insecurity and land degradation have grown as major problems impacting the livelihoods of the people [6-8]. About $52 \%$ of people in Nepal have differing levels of food insecurity [9], although about $68 \%$ of the population engage in agriculture [10]. Currently, community forestry (CF), a forest management approach where local communities are provided with a certain degree of responsibility and authority for 
the forest management is regarded as the most effective way of addressing the subsistence needs of local people [11]. Over the last few decades, CF has been a priority for policy makers [12] to address forest degradation and widespread rural poverty in a single package of programs by mobilizing local people [13]. However, the maximal use by local people has created a heavy pressure in CF thereby inducing land degradation and biodiversity loss [14]. To tackle these issues of degradation and to obtain a high and sustained level of production, agroforestry (AF) has been recognized as the most efficient land management system, as it integrates different land use practices on a single unit of land $[15,16]$. Recently, AF has received significant attention for its efficiency in conserving natural resources along with improving livelihoods [17].

$\mathrm{AF}$ is defined as a land use system in which woody perennials are included within the agricultural landscapes and where both ecological and economical interactions occur between the woody and non-woody components for various social, economic and environmental benefits [18]. AF incorporates the optimal use of the land for the woody and non-woody components and provides several effects on a sustainable basis that are beneficial, such as biodiversity conservation [19], soil erosion mitigation [20], protection of (ground)water quality [21,22] and household food security and income [23].

In Nepal, AF has been practiced in a traditional way where farmers use their agricultural land for propagating trees as an integral part of their farming system $[5,24]$. The promotion of AF as a means of generating income has been included under policies related to agriculture and forests $[25,26]$. Nepal is one of the few countries that has a separate policy for AF. National AF policy [27] aims to prioritize the commercial and collective farming system, facilitate farmers' access to market, promote industry-based AF, provide incentives to farmers adopting AF systems, develop AF on bare, fallow land and develop special area-based AF models [27]. To develop the commercial aspect of AF and site-specific AF models, it is necessary to understand the system adopted by local farmers and the products they derive from it.

Many studies have been conducted regarding AF practices in both the hill and the Terai regions of Nepal. Most of them focus on the linkage between the socioeconomic characteristics of the households and the adoption of AF practices e.g., $[17,24,28]$. The evolution of AF from subsistence to commercial enterprises has been studied by Dhakal et al. [29] for the Eastern Terai of Nepal, whereas other research has highlighted the contribution of AF to rural livelihoods e.g., [30,31]. Similarly, the effect of AF on the quality of soil has also been studied [32,33]. However, studies on the AF systems in the region of most interest, Chure, are still lacking. Because the land in the Chure region is fragile which means the soil in the Chure region is young with low resistance to erosion and vulnerable to degradation [34] and topographically complex in nature, finding the best land management strategy is important [35]. Further, lack of livelihood assets and inadequate food security due to increasing population necessitates the development of an integrated land use system to fulfill these requirements and for conservation purposes [36]. The Chure region has been receiving considerable attention from the government [37]; despite this, the ecological, geographical and biophysical conditions of the region are degrading rapidly [38]. This study was conceptualized to contribute to the sparse knowledge around the AF system in the Chure region.

The objectives of this study are: (i) to assess the major AF systems and farmers' preferences relating to AF species, (ii) to analyze the characteristics of the respondents practicing different AF systems, (iii) to estimate the supply of forest-based products from $\mathrm{AF}$ and compare those with forest-based products obtained from community forestry (CF) and (iv) to understand the status and growth process of AF in the study area.

\section{Materials and Methods}

\subsection{Study Area}

The study was conducted in the Chure region which is located between plain Terai and the mid-hills [35]. It lies within the geographical location of $80^{\circ} 9^{\prime} 25^{\prime \prime}$ to $88^{\circ} 11^{\prime} 16^{\prime \prime}$ 
longitudes and $26^{\circ} 37^{\prime} 47^{\prime \prime}$ to $29^{\circ} 10^{\prime} 27^{\prime \prime}$ latitudes and comprises the youngest mountains in the world [39]. It covers about $12.78 \%$ of the area of Nepal and is among the most fragile ecoregion of Nepal [40]. The Chure region is the most highlighted region considering its heavy vulnerability to mass erosion and landslides caused by heavy deforestation [41] The Government of Nepal has therefore initiated the Chure conservation program through President Chure-Terai Madhesh Conservation Development Committee (hereafter, Chure conservation board) $[42,43]$.

Within the Chure region, the study focused on Makawanpur District, Nepal (Figure 1) that lies between $27^{\circ} 10^{\prime}$ to $27^{\circ} 40^{\prime} \mathrm{N}$ and $84^{\circ} 41^{\prime}$ to $85^{\circ} 31^{\prime} \mathrm{E}$, and covers an area of $2426 \mathrm{~km}^{2}$ [44]. With a wide variation of altitude i.e., $166 \mathrm{~m}$ to $2584 \mathrm{~m}$ above mean sea level, this district accommodates both flatlands and hilly regions [45]. Almost half of the district has a slope inclination greater than $30^{\circ}$, which makes it more vulnerable to landslides and soil erosion [46]. This district experiences an annual mean precipitation of $2535 \mathrm{~mm}$, where the average temperature ranges from $13.3^{\circ} \mathrm{C}$ to $16.6^{\circ} \mathrm{C}$. From south to north, the climate varies from subtropical to temperate [47]. The livelihoods of the population in this district depend upon agriculture; however, the integration of agriculture, forest and pastures was adopted long ago $[48,49]$. The practice of shifting cultivation transitioned into sustainable AF systems due to lack of land ownership [49].

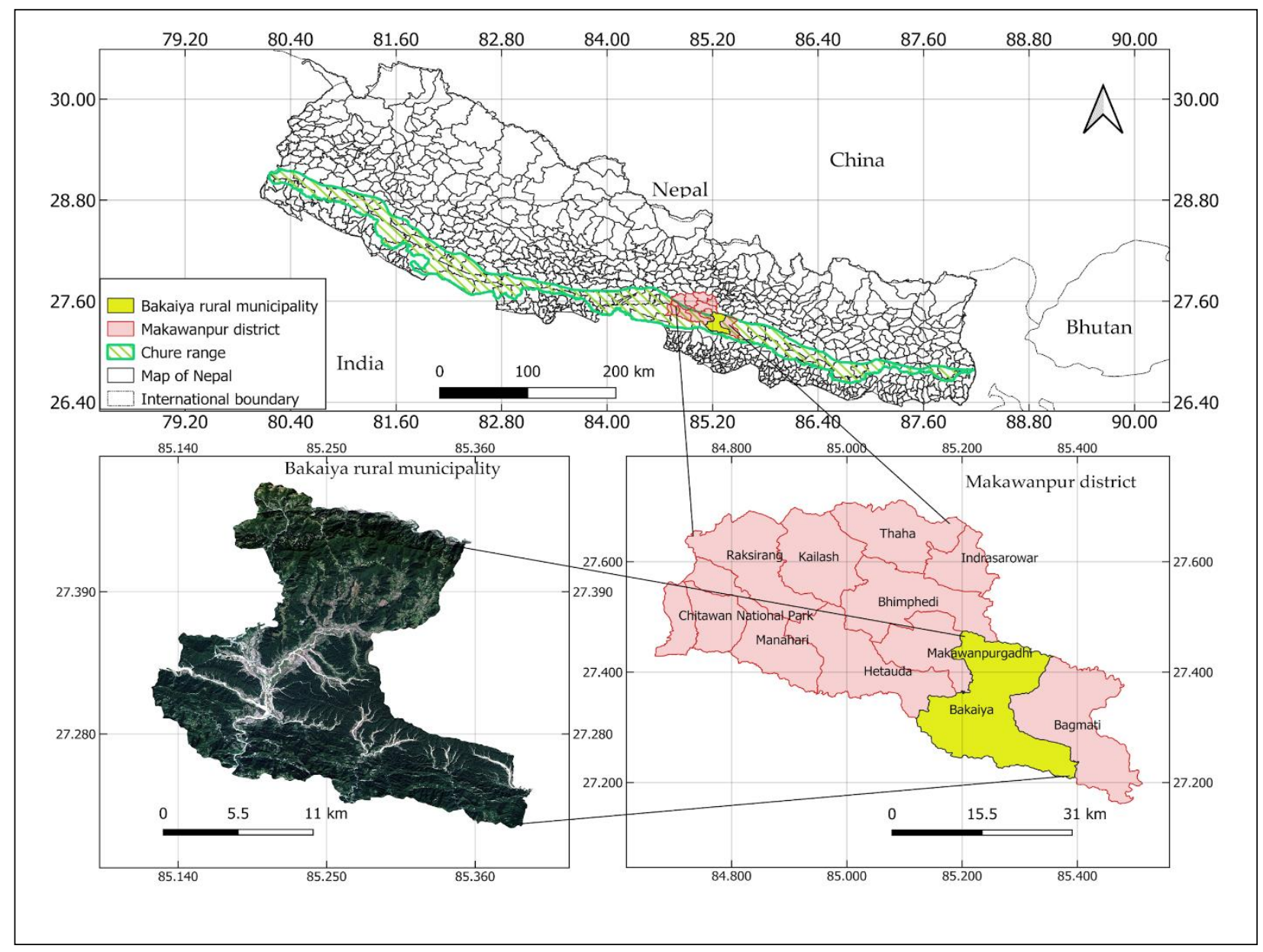

Figure 1. Map showing the study area in Central Nepal.

Studies related to food security and farm-based agroforestry have been conducted in different Village Development Committees (VDCs) of Makawanpur district $[48,50]$. The contribution of agroforestry to the rural livelihood of the Chepang ethnic group in central Nepal has also been documented [51]. Further, the transition of the farming system 
from slash-and-burn farming to permanent agroforestry in Makawanpur district has been studied, and a comparison of the cost and benefits between the two has been done which showed agroforestry as the financially profitable system [52]. Also, the role of agroforestry in conserving tree species was studied by Sharma and Vetaas [53]. However, studies focusing on the choice of agroforestry systems, the supply of forest-based products by farm-based agroforestry and the status of agroforestry in Makawanpur are lacking.

For the specific study site, we consulted with district forest officials and the members of the Chure conservation board. We were interested in the areas where people were more dependent on forest causing severe destruction. Bakaiya rural municipality was listed as a vulnerable region to landslides due to deforestation [54,55] but many people were still dependent on community forests for their livelihood. Agroforestry is regarded as a viable option in fulfilling both agricultural and forest-based products but only about $13 \%$ of total households adopted agroforestry in this area. To understand the socio-economic condition of the people adopting agroforestry, their choice of system, species and the amount of products they acquired from farm-based agroforestry, we selected Bakaiya rural municipality as the study area.

Bakaiya rural municipality is majorly inhabited by the ethnic group-Majhi. Most of the people were dependent on agriculture and labor activities for their livelihood. Very few people were engaged in business, government offices and remittance.

\subsection{Data Collection}

This paper is based on our quantitative research on $\mathrm{AF}$ systems and their contribution to livelihoods in Central Nepal. Out of 1000 households practicing farm-based agroforestry, purposive random sampling was conducted to select the 100 interviewee households. Three key instruments were used: focus group discussions (FGDs), key informant interviews (KII) and semi structured interviews. The semi structured interview was used because we wanted data according to our objective alongside providing the interviewee with open space allowing them to bring up new ideas. FGDs consisted of 25 open-ended questions (Appendix A) focused on the current status of AF systems, their growth processes and the support available for the growth of AF. KII consisted of 13 open-ended questions (Appendix $B$ ) with a focus on the contribution of AF to local livelihoods and the strengths and weaknesses of the AF practices. The interview guide consisted of 27 items (Appendix C) that focused on the major AF systems adopted by the local people and the contributions of AF to their livelihoods compared with those of CF. Prior to data collection, secondary data sources, specifically reports from government agencies such as the Chure Conservation Board the District Forest Office (DFO) and the Ministry of Forests and Environment (MOFE), were reviewed to enhance our understanding of the adoption, use and impact of $\mathrm{AF}$ at district and local levels. The data collection process started with FGD, where five main actors were identified: one community forestry user group, two women's groups, one youth group and one ethnic group (Majhi). Each group consisted of 7-12 individuals who were given the opportunity to express their views. From each focus group we identified one key informant and in addition, five other key informants were selected: one member from the district forest office, one member from Chure Conservation Board, two local leaders and one teacher at the primary school. The individuals from the FDG who had greater knowledge about agroforestry systems and policies and who couldn't discuss openly during focus group discussion were selected as key informants. Other key informants were selected based on their knowledge about agroforestry, governance, national policies and marketing sector. Thus, in total, 10 key informants were interviewed. Interviews with officers of the DFO and the Chure Conservation Board were conducted to gain insights into the role of government in facilitating the AF system at the study site. To understand the participation of local people in the AF system, their choice of system and the contribution of AF to livelihoods, a survey of 100 households was carried out. The interview guides were formulated in English, but the interview was carried out in Nepali language. We tried our best to make local people understand the technical terms 
which made the data interpretation process easier. Additionally, through direct observation, the major species used in the AF systems were determined and further validated with responses from households (Figure 2).

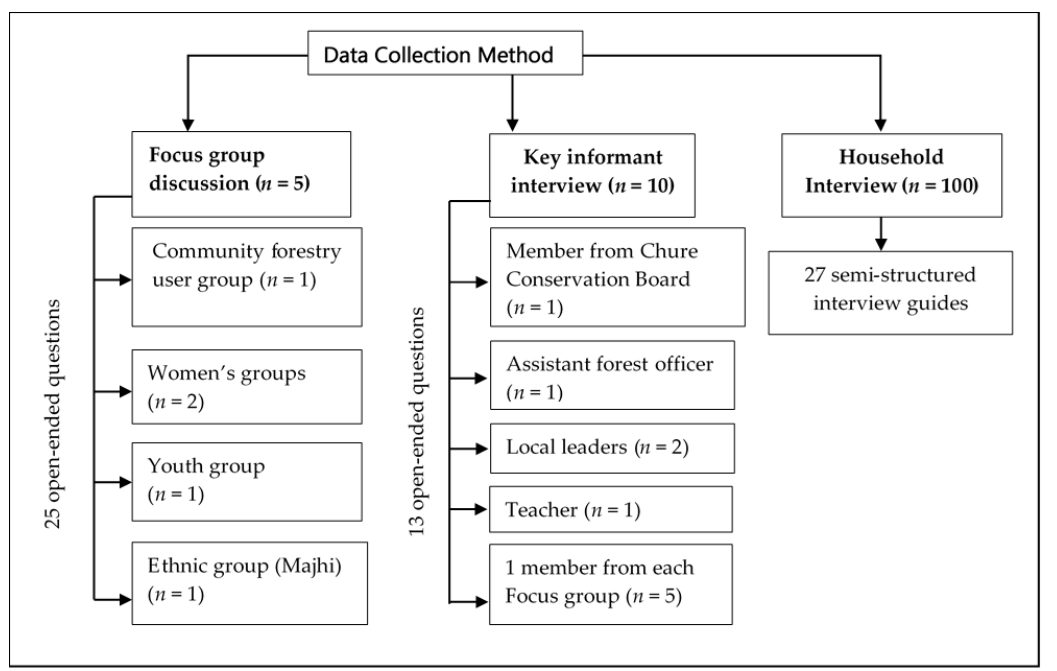

Figure 2. Data collection chart showing the distribution of focus group discussions, household survey and key informant interviews.

\subsection{Data Analysis}

The Shapiro-Wilk test [56] was used to check the normality of the data. Socioeconomic characteristics of respondents were analyzed through descriptive statistics. The KruskalWallis Test [57] was used to assess the significant difference between the AF systems in terms of socioeconomic variables and the supply of forest products. Later, the variable resulting in significant difference was analyzed using the Games-Howell post hoc test (posthocTGH) in R-studio [58] to find the exact pair of AF systems with statistical difference. For the post hoc test, the package userfriendlyscience [59] was used. To analyze the difference in the supply of products between $\mathrm{CF}$ and $\mathrm{AF}$, the Wilcoxon rank-sum test, also called the Mann-Whitney test [60], was employed in R-studio [58].

To assess if the difference in the supply of forest products between different AF systems is statistically significant, the Kruskal-Wallis test was employed with the following hypothesis:

\section{Hypothesis 1.}

Null hypothesis $\left(H_{0}\right)$ : There is no significant difference in the supply of forest products between different AF systems.

Alternative hypothesis $\left(H_{1}\right)$ : There is a significant difference in the supply of forest products between different AF systems.

To assess if the difference in the supply of forest products between AF and CF systems is statistically significant, a Wilcoxon rank-sum test was applied with the following hypothesis:

\section{Hypothesis 2.}

Null hypothesis $\left(H_{0}\right)$ : There is no significant difference in the supply of forest products between AF and CF systems.

Alternative hypothesis $\left(H_{1}\right)$ : There is a significant difference in the supply of forest products between $A F$ and $C F$ systems. 


\section{Results}

\subsection{Agroforestry Systems in the Study Area and the Choice of Plant Species}

In the study area, three farm-based AF systems were adopted by the residents: agrisilvicultural (AS), horti-agri-silvicultural (HAS) and agri-silvi-pastoral (ASP) systems. AS is a system of $\mathrm{AF}$ in which tree species are grown and managed in the farmland together with agricultural crops, whereas HAS is an integrated system of land use, where fruit trees, agricultural crops and timber trees/fuel wood are grown together to meet householders' needs for food grains, fruits, timber and fuel wood [61]. Similarly, under the ASP system the same unit of land is managed to produce agricultural crops and trees/fuelwood and where farmers can also rear animals [61]. Out of 100 respondents, 66 respondents adopted the AS system whereas HAS and ASP systems were adopted by 29 and 5 respondents, respectively. The establishment of trees on farmland was through deliberate retention and management, plantation, or both. The major plant species used in three different AF systems are listed in Table 1.

Table 1. Major species used in different AF systems.

\begin{tabular}{ccc}
\hline System & Crops/Grasses & Tree Species \\
\hline & & Ficus semicordata Buch.-Ham. ex Sm. (Dropping fig), \\
& Oryza sativa L. (paddy rice) & Ficus hispida L. (Fig tree, Litsea polyantha Juss (Litsea), \\
Agri-silvicultural & Premays L. (maize) & Steud. (Negrifolia L. (Wind killer), Ficus roxburghii \\
& Triticum aestivum L. (wheat) & laurel), Ficus religiosa L. (Sacred fig), Bixa orellana L. \\
& Brassica campestris L. (mustard) & (Annato)
\end{tabular}

\section{Crops}

Oryza sativa (paddy rice)

Triticum aestivum (wheat)

Curcuma longa L. (turmeric)

Grasses
Pennisetum purpureum cv. Mott (dwarf elephant
grass)
Setaria splendida Schum.Stapf \& Hubb. (setaria)
Brachiaria brizantha Hochst. Ex A. Rich. Stapf
(Mulato)
Arachis pintoi Krapov \& Gregory (forage peanut)
Thysanolaena maxima Roxburgh O. Kuntze (broom
grass)
Bambusa tulda Roxb. (bamboo)

Ficus semicordata (Dropping fig), Terminalia bellirica Roxb. (Belliric myrobalan), Litsea polyantha (Litsea), Ficus hispida (Fig tree), Ficus infectoria Miq. (White fig), Leucaena leucocephala Lam, de Wit. (Ipil-ipil), Shorea robusta Gaertn. (Sal)

Horti-agrisilvicultural

\section{Crops}

Zingiber officinale Roscoe (ginger)

Curcuma longa (turmeric)

Dioscorea alata L. (yam)

Colocasia esculenta L., Schott. (colocasia)

\section{Vegetables}

Solanum tuberosum L. (potato)

Brassica oleracea var. botrytis L. (cauliflower) Brassica oleracea var. capitata L. (cabbage) Solanum melongena L. (aubergine)

\section{Fodder and firewood trees}

Dalbergia sissoo Roxb. (Indian rosewood), Eucalyptus Camaldulensis Dehnh. (Eucalyptus), Melia azedarach L. (White cedar), Artocarpus lakoocha Roxb. (Monkey tree), Bauhinia longifolia Bong. (Bauhinia), Leucaena leucocephala (Ipil-ipil)

\section{Fruit trees}

Mangifera indica L. (Mango), Litchi chinensis Sonn. (Litchi), Artocarpus heterophyllus Lam. (Jack fruit), Bauhinia longifolia Bong. (Bauhinia), Nyctanthes arbor-tristis L., Ziziphus mauritiana Lam.(Jujube fruit), Prunus persica L.

(Peach), Musa acuminata Colli.(Banana), Citrus maxima Burm. F, Merr (Pomelo), Psidium guajava L. (Guava), Morus indica L. (Black mulberry), Carica papaya L. (Papaya), Ananas comosus L, Merr. (Pineapple), Annona reticulata L. (Wild sweetsop), Areca catechu L. (Palm), Saccharum officinarum L. (Sugarcane) 


\subsection{Socioeconomic Characteristics of the Respondents Practicing Different AF Systems}

Out of 100 households surveyed, the majority i.e., $66 \%$ were females. The average age of respondents was 40 years (range, 17-74 years) and the median age was 36 years. The majority of respondents were from the Tamang ethnic group constituting about $56 \%$ of total households surveyed. About $55 \%$ of total respondents were illiterate and only $6 \%$ were educated up to university level. Therefore, their knowledge about proper AF systems was poor. Agriculture dominated occupations in the study area, with about $52 \%$ of total respondents relying on agriculture for their subsistence needs. The average land holding size of the household was about 14 katha ( 0.48 ha), which is half of the national average of 0.8 ha [62]. However, households practicing the ASP system had the highest land holding of 21 katha ( 0.7 ha) on average. The amount of livestock owned by the household was measured in livestock standard units (LSU). Buffalo, cow, goat and poultry were considered while estimating the LSU. A value of 1 was assigned to mature cows and buffalos, whereas a value of 0.1 was given to goats and 0.03 to poultry [63]. On average, the LSU of households was 3.05. Households that were practicing HAS showed the highest average LSU i.e., 3.36. The accessibility of respondents to a forest was taken into account to understand its impact on the choice of AF system. The distance from the house to a nearby forest was measured in units of time (minutes). On average, respondents required about $19 \mathrm{~min}$ to reach a nearby CF and the minimum and maximum time was found to be $2 \mathrm{~min}$ and $60 \mathrm{~min}$ respectively. The average annual income of those respondents adopting the HAS system was higher in comparison with the other two AF systems (Table 2). When asking about respondents' interest in developing AF, the majority (about 67\%) responded in a positive way, showing a profound interest in developing the AF systems.

Table 2. Characteristics of the respondents in the study area.

\begin{tabular}{|c|c|c|c|c|}
\hline \multirow{2}{*}{$\begin{array}{c}\text { Socioeconomic } \\
\text { Variables }\end{array}$} & \multirow{2}{*}{ Type of Measure } & \multicolumn{3}{|c|}{ Mean Values of the Socioeconomic Variables ( \pm SD) } \\
\hline & & AS $(n=66)$ & $\operatorname{ASP}(n=5)$ & HAS $(n=29)$ \\
\hline Age & Years & $40.67(13.65)^{a}$ & $39.00(20.79)^{\mathrm{a}}$ & $38.76(12.74)^{a}$ \\
\hline Sex & Male $=1$, Female $=2$ & $1.65(0.48)^{\mathrm{a}}$ & $1.4(0.55)^{a}$ & $1.72(0.45)^{\mathrm{a}}$ \\
\hline Education & $\begin{aligned} \text { Illiterate }= & 1, \text { Primary }=2, \text { Secondary }= \\
& 3, \text { University }=4\end{aligned}$ & $1.65(0.91)^{\mathrm{a}}$ & $2(1.22)^{a}$ & $1.82(0.92)^{a}$ \\
\hline Ethnic group & $\begin{array}{c}\text { Tamang }=1, \text { Brahmin }=2, \text { Chettri }=3, \\
\text { Magar }=4, \\
\text { Others }=5\end{array}$ & $2.18(1.54)^{\mathrm{a}}$ & $1.8(1.09)^{\mathrm{a}}$ & $2.14(1.61)^{\mathrm{a}}$ \\
\hline Major occupation & $\begin{array}{c}1=\text { Agriculture, } 2=\text { Government } \\
\text { employee, } 3=\text { Non-Government } \\
\text { employee, } 4=\text { Business, } 5= \\
\text { Remittance, } 6=\text { Wage Labour }\end{array}$ & $2.59(1.86)^{\mathrm{a}}$ & $1.00^{\mathrm{b}}$ & $2.66(2.04)^{\mathrm{a}}$ \\
\hline Livestock unit & Livestock standard unit (LSU) & $2.91(1.84)^{\mathrm{a}}$ & $3.11(2.05)^{a}$ & $3.36(2.22)^{a}$ \\
\hline Land holding & Katha (30 Katha = 1 hectare) & $13.02(7.79)^{\mathrm{a}}$ & $21.6(7.23)^{\mathrm{a}}$ & $16.05(9.00)^{\mathrm{a}}$ \\
\hline Annual cash income & NRs (Nepalese Rupees) & $150,455(85,150)^{a}$ & $110,000(82,158)^{a}$ & $161,035(57,591)^{\mathrm{a}}$ \\
\hline Time to reach forest & Minutes & $19.94(13.25)^{a}$ & $18(7.58)^{\mathrm{a}}$ & $16.69(10.82)^{a}$ \\
\hline $\begin{array}{l}\text { Interest in developing } \\
\text { agroforestry }\end{array}$ & $\begin{array}{l}0=\text { No } \\
1=\text { Yes }\end{array}$ & $0.65(0.54)^{\mathrm{a}}$ & $0.6(0.55)^{\mathrm{a}}$ & $0.79(0.41)^{\mathrm{a}}$ \\
\hline
\end{tabular}

Values in parenthesis are the \pm SD of the socioeconomic variables. The similar letter in superscript indicates the nonsignificant difference between agroforestry systems in pairwise comparison. AS = agri-silvicultural, ASP = agri-silvi-pastoral, HAS = horti-agri-silvicultural . ${ }^{\mathrm{a}}=$ The similar letter in superscript indicates the nonsignificant difference between agroforestry systems in pairwise comparison.

\subsection{Supply of Forest Products from Different Agroforestry Systems}

Fodder, fuelwood and leaf litter were the major forest products derived from AF systems, and therefore, the difference between AF systems was estimated for these three forest products. The local people derived a higher amount of forest products from ASP. The average annual fodder supply from ASP was higher $(6000 \mathrm{~kg})$ in comparison with HAS $(3600 \mathrm{~kg}$ ) and AS (3222 kg) (Figure 3a) Similarly, ASP provided a higher average annual fuelwood supply (1875 kg) than AS (1048 kg) and HAS (760 kg) (Figure 3b). Moreover, ASP provided a higher average annual leaf litter supply $(2900 \mathrm{~kg})$ compared with AS $(2610 \mathrm{~kg})$ 
and HAS (1700 kg) (Figure 3c). The $p$-values obtained from Kruskal-Wallis test for all the products were greater than 0.05 at the $95 \%$ confidence interval, the null hypothesis was accepted, implying that the difference in the supply of forest products from different AF systems was not statistically significant (Table 3 ).

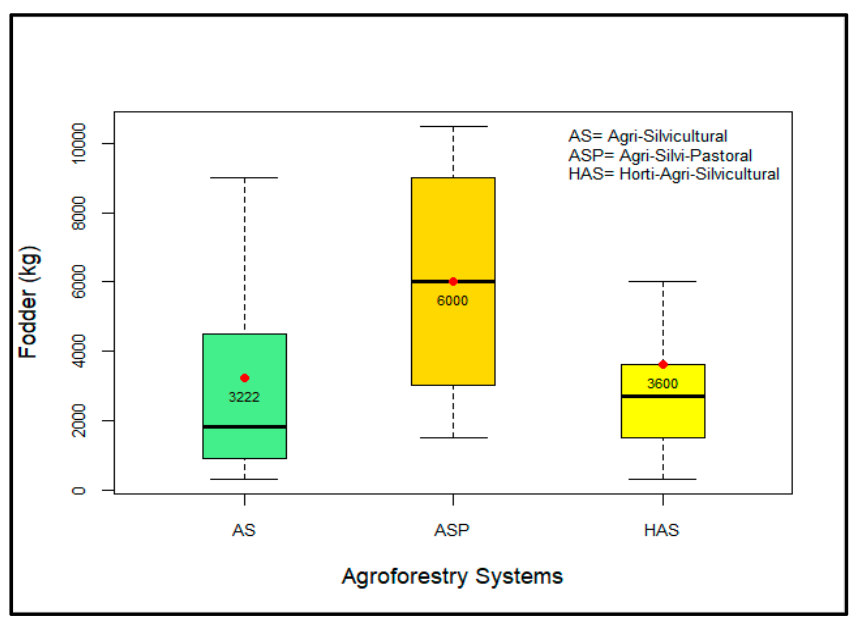

(a)

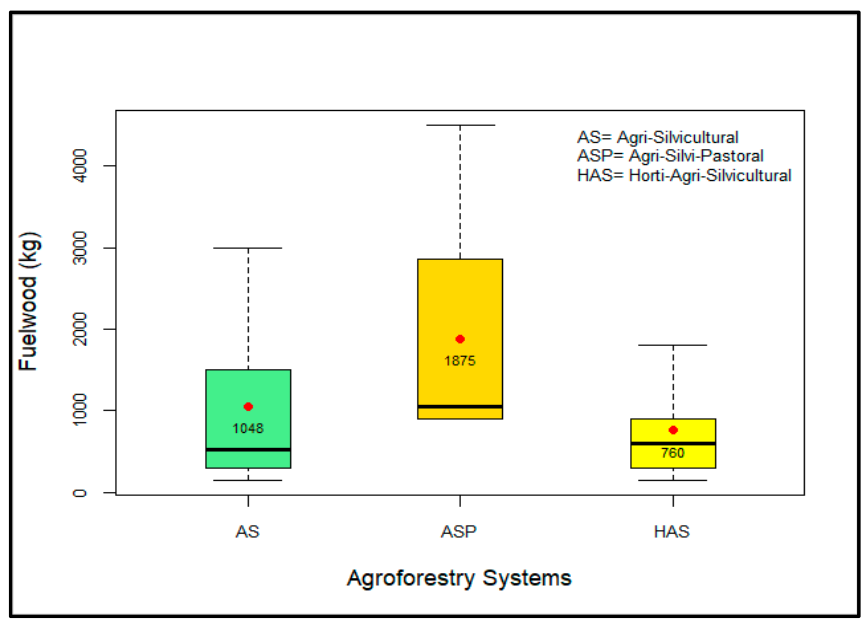

(b)

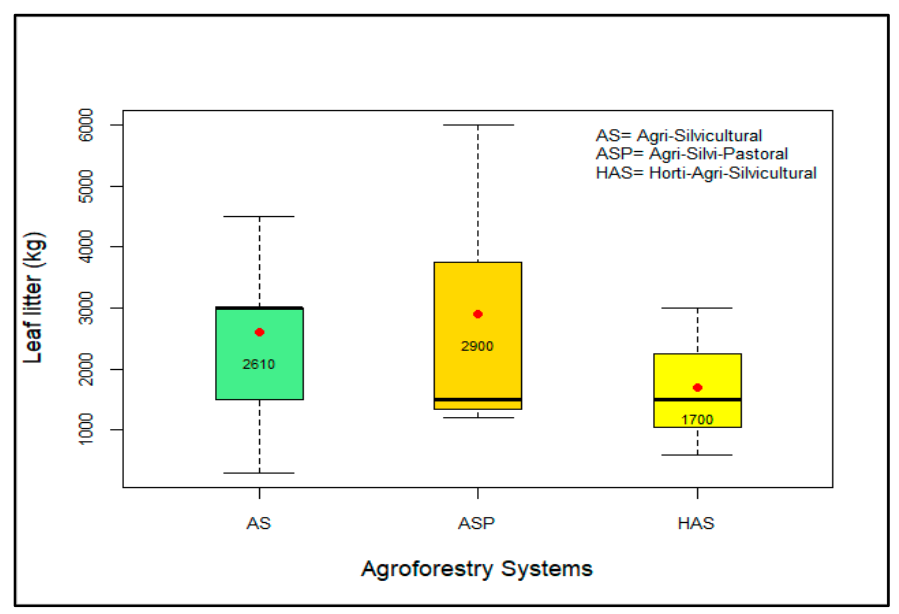

(c)

Figure 3. The average annual supply of forest products from different agroforestry systems in kilograms; (a) fodder, (b) fuelwood and (c) leaf litter where a red dot indicates the mean while a black line indicates the median.

Table 3. Kruskal-Wallis test result for Hypothesis 1 *.

\begin{tabular}{ccc}
\hline Forest Products & Chi-Square & $p$-Value \\
\hline Fodder & 3.7 & 0.15 \\
Fuelwood & 2.93 & 0.23 \\
Leaf litter & 1.06 & 0.58 \\
\hline
\end{tabular}

$\bar{*}=$ Null hypothesis $\left(\mathrm{H}_{0}\right)$ : There is no significant difference in the supply of forest products between different $\mathrm{AF}$ systems.

Alternative hypothesis $\left(\mathrm{H}_{1}\right)$ : There is a significant difference in the supply of forest products between different AF systems. 


\subsection{Contribution of Forest Products from AF and CF Systems}

A comparison was made between the annual supply of forest products from $\mathrm{AF}$ and CF systems. The total supply of forest based products were measured in terms of the amount derived by local households in one year. The average annual supply of fodder from CF was higher $(4791 \mathrm{~kg})$ than that from the AF system $(3483 \mathrm{~kg}$ ) (Figure 4). The average annual supply of fuelwood from CF was higher than that from AF (i.e., $3085>1012$ ). The average annual supply of leaf litter by CF was higher (3466 kg compared with $2494 \mathrm{~kg}$ from $\mathrm{AF})$. Thus, it was evident that the local people relied mainly on CF for their forest products. About $75 \%$ of fuelwood demand was fulfilled through CF, whereas in the case of fodder and leaf litter, the contribution was around $57 \%$. It can be hypothesized that people used the AF system for the fulfilment of fodder and leaf litter requirements, and the choice of species was similarly affected.

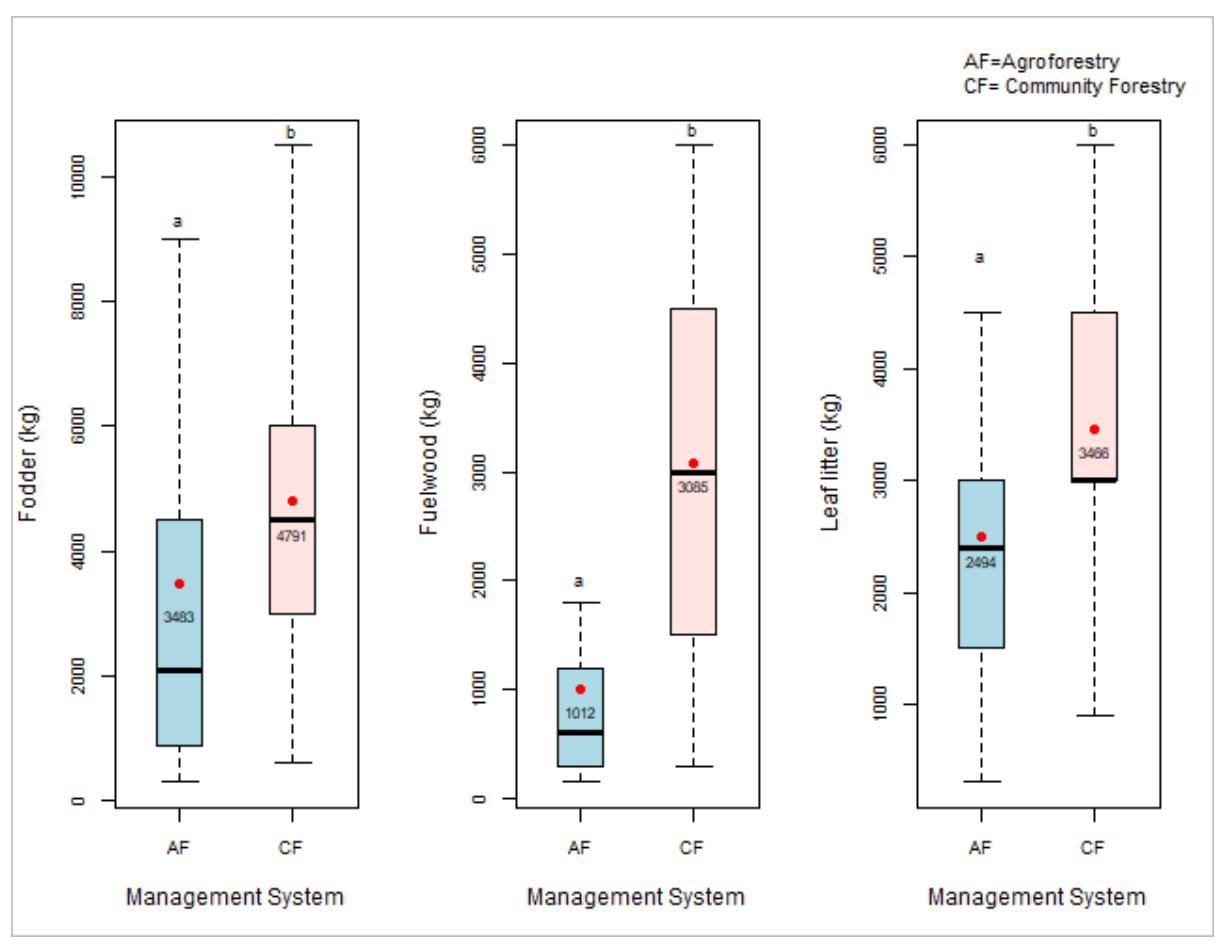

Figure 4. The average annual supply of forest products (fuelwood, fodder, leaf litter) from AF and CF systems where a red dot indicates the mean value while a black line indicates the median. The different letters ( $a$ and $b$ ) denotes the significance difference between the mean values.

Using Wilcoxon test for Hypothesis 2 at the $95 \%$ confidence interval, all the $p$-values were less than 0.05 , null hypothesis was rejected, implying that the difference in the supply of all forest products from AF and CF systems was statistically significant (Table 4).

Table 4. Wilcoxon test result for Hypothesis 2 *.

\begin{tabular}{ccc}
\hline Forest Product & Wilcoxon Test Statistic $(W)$ & $p$-Value \\
\hline Fodder & 2242.5 & $<0.001$ \\
Fuelwood & 827 & 0.001 \\
Leaf litter & 273.5 & 0.01 \\
\hline * Null hypothesis $\left(\mathrm{H}_{0}\right):$ There is no significant difference in the supply of forest products between AF and CF \\
systems.
\end{tabular}

Alternative hypothesis $\left(\mathrm{H}_{1}\right)$ : There is a significant difference in the supply of forest products between $\mathrm{AF}$ and $\mathrm{CF}$ systems. 


\subsection{Status and Growth of Agroforestry in the Study Area}

Through FGDs and KIIs, the status of AF in terms of its potency and limitations were assessed along with the advantages and disadvantages of further growth of this system at the study site. While the allocation of a small unit of land to provide multiple benefits is a very important aspect of $\mathrm{AF}$, the local people were unaware of $\mathrm{AF}$ systems, and therefore no scientific techniques were employed at the study site. The lack of appropriate tools, irrigation facilities and high-yielding varieties of seed were major limitations in the promotion of AF systems in this region. Due to the fragile soils of the Chure region, the fact that planted seedlings and crops may be swept away by floods and destroyed by landslides was also a considerable hindering factor in the adoption of AF systems in this region. The majority of households had medium and small land holdings. Thus, the use of limited land for trees along with agricultural crops would reduce food production, which may be a serious problem for poor farmers. Those who retained tree species on their farmland were less motivated to embrace the notion of a plantation. Although there was high potential for the fruit tree species because of the suitable soil properties, people were not interested in planting fruit trees. The committee of the community forestry user group was active at the study site to manage and develop $\mathrm{CF}$, but a similar committee for AF was lacking, showing there was greater interest in administering the growth of CF. As regards $\mathrm{AF}$, there is a sufficiency of low-skilled manpower, little investment is required and it is simple to adopt the necessary practices. With less input than is needed for CF, AF provides maximum output. Because Chure falls in a critical zone of Nepal, several government and nongovernment organizations have shown an interest in Chure conservation, which may provide the greatest opportunity for the implementation and promotion of AF. However, the focus on conservation was at odds with the promotion of AF systems. No external or internal agencies were found to support the use of AF techniques in this region. Also, no funding was allocated for the development of $\mathrm{AF}$ in this region.

However, this lack of foresight on the part of the government was contrasted by some key informants who commended the efforts of local government in organizing training sessions on AF systems, facilitating the choice of species and distributing the required seedlings. The focus groups disagreed with this, explaining that it led to ineffectiveness caused by speculative guidance. The insufficiency of distributed seedlings demotivated the farmers from diversifying their land and planting local species. On a positive note, youths were interested in developing AF systems and were aware of potential markets, which led to the evolution of the choice of species from subsistence to cash crops and vegetables. Youth groups were motivated to commercialize their farm production and therefore, the development of markets and enterprises although slow, had begun. Since women were responsible for the collection of fuelwood and fodder from the forest, they showed greater interest in developing AF as it could enhance easy access to these needs. But women played a minimal role in the decision-making process, and therefore, $\mathrm{AF}$ in the study area was much less developed. Even among those taking part in the focus groups and KIIs, many did not know the details of this policy and how it would benefit the local farmers. However, the development of AF in the near future was anticipated.

\section{Discussion}

\subsection{Choice of AF System and Plant Species}

Out of 12 AF systems documented by the Forest Research and Training Center (FRTC) [64] in hilly and Terai regions of Nepal, the people of the study area adopted only three of those: AS, ASP and HAS. This may be because they do not have the proper level of knowledge about the various AF systems, which could be associated with the higher illiteracy level at the study site. Since $52 \%$ of local people were engaged in agriculture as the main occupation, any diversification of land use was minimal owing to the prioritization of subsistence crops for the fulfillment of basic needs. Similar reasons were mentioned by Kiptot and Franzel [65] in their study in Africa. Kassie [66], in Ethiopia, discovered that the people who were engaged in more diverse income sources would adopt 
various AF systems, which supported the findings of Dhakal and Rai [28]. The choice of crops worldwide has developed over time from food crops to cash crops and vegetables. As explained by Dhakal et al. [29], the pattern of the farming system has changed over time. The change was linked with the growth of the market in many cases $[29,30,67]$, which was also observed at our study site.

AS was the most dominant AF system in the study area, possibly because of the small size of land holdings of the people. AS is the most common AF system in both hilly and Terai regions of Nepal, as also determined by FRTC [64] and Amatya et al. [68]. Since the landholding size of the respondents was below the national average, the integration of different systems on a small unit of land would restrict the space available for crop production, thereby inducing food insecurity. Therefore, most of the people relied on the simple AS system. The influence of landholding size on the adoption of AF systems was noted by different researchers [28,69,70].

As Dhakal et al. [29] mentioned, the choice of tree species is affected by the farmer's priority. Since the production of timber would take several years, people opted instead for fodder and fruit species. Which local fodder species are preferred by farmers in different countries has been analyzed in many studies, e.g., [71-73]. The findings of our study are in line with those of Kunwar et al. [74] for Nepal, as different Ficus species that are indigenous to Nepal were used by most of the farmers. Despite the higher potentiality of HAS to improve the livelihoods of the farmers by providing extra income, farmers still view that system as less profitable, which is a valid argument due to a lack of commercial prospects. The study by Snelder et al. [75] in the Philippines also discovered negative perceptions among farmers in regard to fruit species in comparison with seasonal cash crops.

\subsection{Agroforestry for the Support of Rural Livelihoods in Comparison with Community Forestry}

Since the focus of this study was on the supply of forest-based products from AF, the benefits of $\mathrm{AF}$ in regard to cash crops and fruit production were not studied. The major forest-based products used by local people in this study area were fuelwood, fodder and leaf litter. Even though more than $69 \%$ of people depend on fuelwood as their main source of energy in Nepal [76], the AF system in our study area contributed only $25 \%$ of the total demand; the remaining $75 \%$ was derived from CF. The dependency of people in $\mathrm{CF}$ for energy sources is well documented by many studies, e.g., $[5,77,78]$. However, the insufficiency of AF in meeting the fuelwood demand in the study area could be associated with the preference for palatable fodder species by the farmers for their livestock. As explained by liyama et al. [79], in the context of Africa, the adoption of AF with a focus on fuelwood is minimal and therefore pressure is placed on the natural forest. The use of multipurpose trees or of rotational woodlots with fast growing species could address this issue [79].

In the case of fodder and leaf litter, the contribution of AF systems and CF were almost equal, which implies that the dependency on the natural forest for these products is slowly decreasing. A study in Indonesia also showed a strong linkage between farm diversification and low dependency on natural forest [80]. Enabling farmers to integrate multiple species rather than monocultures could minimize the pressure on the adjacent forest [80]. The study by Rahman et al. [81] in Bogor, Indonesia stated that the use of natural forests by farmers adopting subsistence agriculture is much higher than that among farmers adopting AF systems.

Despite the wide opportunities provided by AF of sustaining subsistence and commercial livelihood aspects, the policy implications restrict the use of some trees as an income-generating source [82]. Even though AF makes a significant contribution to livelihoods, it does not have a strong policy base [5]. Therefore, CF is still the first choice of poor farmers with less land holding capacity [83]. While $44 \%$ of the country's total land area is covered by forest, there has been a gradual decrease in the extent of the forests of the Chure region $[39,84]$, a trend that is even more pronounced in and around the agricultural areas of Nepal [31]. Research studies have shown there are direct connections between forest 
degradation and poverty [85]. Owing to the large population in poverty and unemployed in the Chure region [37], AF has a strong potential to Supplement CF in this region by reducing the pressure on $\mathrm{CF}$. Along with the supportive roles they play in relation to each other, CF and AF make remarkable contributions to livelihoods.

As an integrated approach, agroforestry plays a multifunctional role in achieving the agenda 2030 by increasing the yields /farms output significantly and achieving food security towards SDG-2, and can reduce poverty (SDG-1) by enhancing the income with diversified income opportunities. The role played by AF in the study area to conserve the biodiversity and ecosystem services (SDG-15) while reducing the pressure on CF for fodder, fuelwood and litter is remarkable. Furthermore, AF acts as the source of energy (SDG-7) by providing fuelwood. Several studies highlight the role of agroforestry to achieve various goals under agenda 2030 e.g., [86-88]. The role of CF in making contributions to SDGs has been widely recognized in many research studies e.g., [89-91]. Along with the complementary role played to each other, $\mathrm{AF}$ and $\mathrm{CF}$ have strong potentiality to make remarkable contributions to SDGs.

\subsection{Prospects for Growth of Agroforestry}

The major restrictions in the proper development of AF at the study site were the lack of awareness of local people around greater diversification around AF systems and lack of technical knowledge. Dhakal and Rai [28] in their study in Dhanusha, Nepal also found that the improved accessibility of farmers to extension services had a positive influence on the adoption of a variety of AF systems. As in the case of Rwanda, where farmers declined the adoption of AF systems due to a lack of technical expertise, capital and quality seeds [92], this study also found the lack of scientific techniques, funding and availability of seedlings to be the major limitations for the adoption of AF systems. With the transfer of knowledge to farmers regarding the selection of appropriate species, and techniques of tree planting and harvesting, the growth of AF systems could be ensured. A study in Africa by Meijer et al. [69] has also explained the linkage of perceptions of local people about $\mathrm{AF}$ to the knowledge they have. While AF is practiced at the study site for subsistence needs, there are no well-developed markets for farmers' AF products such as fruits and non-timber forest products. Research conducted by Gilmour et al. [5] showed that the unavailability of a proper market has been a drawback that limits the development of AF systems.

There is a gap in the demand and supply chain of forest products from AF in the study area, so there is an immediate need to innovate and improve the current system of AF. There is great opportunity for the conservation of fragile Chure regions through AF by enhancing livelihood productivity; this would give higher economic returns and other related opportunities. Nepal is one of few countries with an AF policy that aims to prioritize the commercialization and collective advantages of AF systems and to facilitate farmers access to the market [27]. The policy further aims to provide incentives to those farmers adopting an AF system and to generate specific area-based AF models. However, the implementation at rural ground level is still deficient. Lack of proper laws and directives and organizational incompetence has restricted the successful implementation of this policy. Furthermore, the provision of harvesting, transportation and marketing of commercial timber from agroforestry is completely contradictory with existing forest law [93]. The feasibility of the commercial use of forest products from community forests has caused a drawback in developing agroforestry. Even though much remains to be done around the development of AF systems in different parts of Nepal, the initiation of promotion through the formulation of policies has created an anticipation of better AF systems. To increase the adoption of AF among the stakeholders, positive perceptions around AF could be built through extension services and technical training. 


\section{Conclusions}

In conclusion, the practice of farm-based agroforestry in the study area was more traditional, which has eventually grown from sustenance to commercial. The adoption of agroforestry in the study area was much limited as people lacked knowledge about the multiple uses of land and were not prepared to take risks with small land holdings. Only three farm-based agroforestry systems: AS, HAS and ASP were practiced by the local people. The supply of forest products from ASP was higher than other systems in spite of a low number of respondents practicing it. People still relied on the community forests for the products thereby creating pressure on natural forests. Agroforestry though has a significant potential to contribute to livelihoods with fewer inputs, the horizon of its practice was restricted by the lack of technological development and market availability. Proper extension services, supply of proper raw materials to the farmers and development of markets would help agroforestry to prosper in this region alongside reducing the heavy forest degradation. This study recommends further comprehensive study on the motivational drivers for agroforestry, competence of policies in developing agroforestry, quantitative measure of the contribution of agroforestry to the total income of local people and the pertinence of the market for agricultural and forest products in this area.

Author Contributions: Conceptualization, D.K.; Methodology, A.A. and D.K.; Software, K.P.B. and B.P.D.; Validation, A.A. and H.B.; Formal Analysis, K.P.B. and B.P.D.; Investigation, D.K.; Resources, D.K.; Data Curation, A.A. and D.K.; Writing-Original Draft Preparation, A.A. and B.P.D.; WritingReview \& Editing, H.B. and K.P.B.; Visualization, D.K.; Supervision, H.B.; Project Administration, B.P.D.; Funding Acquisition, D.K. All authors have read and agreed to the published version of the manuscript.

Funding: This research received no external funding.

Institutional Review Board Statement: Not applicable.

Informed Consent Statement: Informed consent was obtained from all subjects involved in the study.

Data Availability Statement: The data presented in this study are available on request from the corresponding author.

Acknowledgments: We acknowledge the financial contribution from the Nepal Agroforestry Foundation (NAF) to carry out this research and CGIAR research program on Forests, Trees and Agroforestry for the partial support to publish the work. The staff of Terai Private Forest Development Association (TPFDA) are also acknowledged for their support during data collection. The authors extend thanks to Nab Raj Subedi who helped produce the study area map. We appreciate the reviewers' comments and suggestions.

Conflicts of Interest: The authors declare no conflict of interest.

\section{Appendix A}

Questionnaire for focus group discussions

1. How well do you understand agroforestry?

2. Are you aware of different types of agroforestry systems?

3. Do you have any idea about the scientific techniques of agroforestry?

4. Which species do you think is beneficial (timber, fodder, fuelwood, fruit)?

5. How do you evaluate the benefit of agroforestry?

6. Do you think agroforestry can provide more benefits than the community forest?

7. Would you prefer agroforestry over subsistence agriculture?

8. Are you interested in developing agroforestry?

9. Which type of support are you receiving from the government?

10. Do you think that the support from the government is enough as well as inclusive?

11. Are there any other organizations supporting agroforestry in this area?

12. What kind of support do you expect from the government? 
13. Is there any committee for agroforestry development in the area?

14. Are you planning to form any such committee?

15. What motivates you to adopt agroforestry?

16. What restricts you from adopting agroforestry?

17. Are there enough markets where you can sell the products from your farm?

18. If yes, are you satisfied with the market price of the agroforestry products?

19. Do you think increasing size of markets could help in developing agroforestry in this region?

20. Do you have any suggestions to improve agroforestry?

21. Do you think agroforestry is well-promoted in this region?

22. Are you willing to participate in any forms of training related to agroforestry?

23. Do you think equal attention is given to agroforestry and community forestry?

24. Are you aware of the recent agroforestry policy?

25. If yes, do you think this will help toward the development of an agroforestry system in your area?

\section{Appendix B}

Questionnaire for Key Informant Interview

1. Do people in the study area know about agroforestry practices?

2. Are you aware of any scientific techniques used for the practices of agroforestry?

3. Are villagers interested in private agroforestry? If yes, what is the trend for developing private agroforestry?

4. Is there any committee for the development of an agroforestry system? If yes, what is the name of the committee involved?

5. How do you evaluate the efforts of the central and local governments in promoting agroforestry?

6. Are NGOs and INGOs involved in the development of an agroforestry system?

7. If yes, do they provide any type of funding for the development of an agroforestry system?

8. What are the possible agroforestry techniques that could be practiced here?

9. What are the constraints for developing farm-based agroforestry?

10. What are the opportunities for agroforestry promotion on this site?

11. What are the agroforestry practices that can give maximum benefit and reduce pressure in natural forests?

12. Are you convinced that agroforestry could contribute to decreasing pressure in natural forests as they supply major forest products? If yes, why? If no, why?

13. At last, would you like to suggest any agroforestry practice that would be suitable for this area?

Interview Guide

\section{Appendix C}

\section{Socioeconomic characteristics}

1. Name of Respondent:
i. Age:
ii. Sex:
iii. Address:
iv. Ethnic group: (a) Tamang
(b) Brahmin (c) Chettri (d) Magar (e) Others

2. Annual cash income of family. NRs.

3. Educational status of family:

\begin{tabular}{|c|c|c|c|c|c|c|c|c|c|}
\hline \multicolumn{10}{|c|}{ Number of Family Members with Their Educational Status } \\
\hline \multicolumn{2}{|c|}{ Illiterate } & \multicolumn{2}{|c|}{$\begin{array}{l}\text { Primary } \\
\text { (1-5 class) }\end{array}$} & \multicolumn{2}{|c|}{$\begin{array}{l}\text { Secondary } \\
\text { (6-10 class) }\end{array}$} & \multicolumn{2}{|c|}{$\begin{array}{l}\text { Higher Secondary } \\
\text { (10-12 class) }\end{array}$} & \multicolumn{2}{|c|}{ University } \\
\hline M & $\mathrm{F}$ & $\mathrm{M}$ & $\mathrm{F}$ & $\mathrm{M}$ & $\mathrm{F}$ & $\mathrm{M}$ & $\mathrm{F}$ & $\mathrm{M}$ & $\mathrm{F}$ \\
\hline
\end{tabular}


4. What is your major occupation?

\begin{tabular}{cc}
\hline Types & Choice \\
\hline Agriculture \\
\hline Government employee \\
\hline Non-gov. employee \\
\hline Business \\
\hline Pension \\
\hline Remittance \\
\hline Wage laboring \\
\hline Others
\end{tabular}

5. Livestock standard units

\begin{tabular}{cc}
\hline Types of Animal & LSU \\
\hline Buffalo \\
\hline Cow \\
\hline Goat \\
\hline Poultry \\
\hline Others
\end{tabular}

6. Land holding:

\begin{tabular}{ccc}
\hline Land Types & Registered Land Area (in ha) & Unregistered Land Area (in ha) \\
\hline Khet (Large Productive Agricultural Land) & \\
\hline Bari (Medium Productive Agricultural Land) & \\
\hline Kharbari (Poor Productive Agricultural Land) & \\
\hline Home garden & \\
\hline
\end{tabular}

7. Area of home garden (Farm-based agroforestry) $\ldots \ldots \ldots \ldots \ldots$ (in ha).

8. Time to reach forest from household ............ in minutes/hours.

9. Time to reach the road head from household .............. minutes/hours.

10. Free grazing months in your farm-based agroforestry in the whole year........................

11. Number of fodder collection months in your farm-based agroforestry in the whole year ...... months.

\section{Supply from agroforestry}

12. Do you think planting trees along with agricultural crops is a good idea?
(a) Yes
(b) No
(c) Do not know

13. Have you planted trees with agricultural crops? (If no, go to Q.N. 15)
(a) Yes
(b) No
(c) Do not know

14. If yes, what types of trees are more preferable to plant on your farmland?
(a) Fodder
(b) Fuel wood
(c) Timber
(d) Fruit tree

15. In your opinion, why do you plant trees on your farmland? (Please Tick $\square$ one or more)
(a) For fodder
(b) For timber
(c) For fuel wood
(d) For soil conservation
(f) For aesthetic value
(g) To increase land productivity
(h) Others (Specify.
(e) For income

16. What are the methods of establishment of farm trees? \{Please Tick $\square$ one\}
(a) Deliberate retention and management of natural regeneration
(b) Plantation
(c) Both a and b 
17. What are your sources of firewood collection? (Tick $\sqrt{ }$ one or more than one)

(a) Community forest (b) Agroforestry (c) National forest (d) Private forest

(e) Buy from market (f) Others

18. What are the sources of tree fodder for your cattle? (Tick $\sqrt{ }$ one or more than one)

(a) Community forest (b) Agroforestry (c) National forest (d) Private forest

(e) Buy from market (f) Others.

19. What are the sources of forage for your cattle? (Tick $\sqrt{ }$ one or more than one)
(a) Community forest (b) Agroforestry (c) National forest (d) Private forest
(e) Buy from market (f) Others

20. What are the sources of timber for your household?
(a) Community forest
(b) Agroforestry (c)
(c) National forest (d)
(d) Private forest (e) Buy from market
(f) Others

21. What are the sources of forest products for your household consumption?
(a) Community forest
(b) Agroforestry (c)
(c) National forest (d)
d) Private forest (e) Buy from market
(f) Others

22. Are you interested in developing an agroforestry system?
(a) Yes
(b) No
(c) Do not know

23. If yes, what are the reasons behind developing agroforestry?
(a) Increased crop yield
(d) Soil quality improvement
(b) Increased biodiversity
(e) Healthy environment
(c) Livestock benefits
(f) Soil conservation
(g) Others

24. Estimate the contribution of different forest product needs to your household/year.

\begin{tabular}{cccccc}
\hline \multirow{2}{*}{ Forest Product } & \multicolumn{3}{c}{ Agroforestry } & \multicolumn{2}{c}{ Community Forest } \\
\cline { 2 - 5 } & Unit & Price/Unit & Qty & Unit & Price/Unit \\
\hline Timber & & & \\
\hline Pole & & \\
\hline Fuelwood & & \\
\hline Fodder & & \\
\hline Others (specify ....) & & \\
\hline
\end{tabular}

25. How often do you visit to collect forest products from natural forest? (Tick $\square$ one)
(a) Daily (b)
(b) Weekly
(c) Monthly (d)
(d) Yearly

26. How often do you visit to collect forest products from your farm-based agroforestry? (Tick $\square$ one)

(a) Daily (b) Weekly (c) Monthly (d) Yearly

27. List the major tree species available in your farm-based agroforestry.

\begin{tabular}{cccc}
\hline S. $\mathbf{N}$. & Name of Species & Uses & No. of Plants \\
\hline 1 & & \\
\hline 2 & & \\
\hline 3 & & \\
\hline 4 & & \\
\hline
\end{tabular}




\section{References}

1. UN General Assembly, Transforming Our World: The 2030 Agenda for Sustainable Development, 21 October 2015, A/RES/70/1. Available online: https://www.refworld.org/docid/57b6e3e44.html (accessed on 1 December 2020).

2. Fisher, E.; Bavinck, M.; Amsalu, A. Transforming asymmetrical conflicts over natural resources in the Global South. Ecol. Soc. 2018, 23, 234. [CrossRef]

3. Rauch, T.; Schmidt, M.; Segebart, D. New rural dynamics and challenges in the Global South. Geogr. Helv. 2014, 69, 225-226. [CrossRef]

4. Varughese, G. Coping with changes in population and forest resources: Institutional mediation in the middle hills of Nepal. In Forest Resources and Institutions; Chapter 8; Forests, Trees and People Programme, Working Paper; FAO: Rome, Italy, 1998.

5. Gilmour, D.; Pradhan, U.; Malla, Y.; Bartlett, T.; Finlayson, R.; Shah, R. Enhancing Livelihoods and Food Security from Agro-Forestry and Community Forestry Systems in Nepal: Current Status, Trends, and Future Directions; Southeast Asia Regional Program; World Agro-forestry Centre (ICRAF): Bogor, Indonesia, 2014.

6. Deshar, B.D. An overview of agricultural degradation in Nepal and its impact on economy and environment. Glob. J. Econ. Soc. Dev. 2013, 3, 1-20.

7. Chalise, D.; Kumar, L.; Kristiansen, P. Land Degradation by Soil Erosion in Nepal: A Review. Soil Syst. 2019, 3, 12. [CrossRef]

8. Paudel, P.P.; Devkota, B.D.; Kubota, T. Land Degradation in Nepal: A Review on its Status and Consequences. J. Fac. Agric. Kyushu Univ. 2009, 54, 477-479. [CrossRef]

9. Government of Nepal (GoN). Nepal Demographic and Health Survey, Government of Nepal; Ministry of Health and Population, Ramshah Path: Kathmandu, Nepal, 2016. Available online: https://www.dhsprogram.com/pubs/pdf/fr336/fr336.pdf (accessed on 2 December 2020).

10. United States Agency for International Development (USAID). Agriculture and Food Security. 2020. Available online: https: //www.usaid.gov/nepal/agriculture-and-food-security (accessed on 5 December 2020).

11. Charnley, S.; Poe, M.R. Community Forestry in Theory and Practice: Where Are We Now? Annu. Rev. Anthr. 2007, 36, 301-336. [CrossRef]

12. Gauld, R. Maintaining Centralized Control in Community-based Forestry: Policy Construction in the Philippines. Dev. Chang. 2000, 31, 229-254. [CrossRef]

13. Maryudi, A.; Devkota, R.R.; Schusser, C.; Yufanyi, C.; Salla, M.; Aurenhammer, H.; Rotchanaphatharawit, R.; Krott, M. Back to basics: Considerations in evaluating the outcomes of community forestry. For. Policy Econ. 2012, 14, 1-5. [CrossRef]

14. Shrestha, K.; Cedamon, E.; Ojha, H.; Sharma, N.; Paudel, B.H.P.; Amatya, S.M.; Joshi, M.; Karki, R.; Dangal, S.; Shah, R. Enhancing Livelihoods and Food Security from Agroforestry and Community Forestry in Nepal (EnLiFT1); ACIAR: Bruce, Australia, 2018.

15. Conacher, A. Land degradation: A global perspective. N. Z. Geogr. 2009, 65, 91-94. [CrossRef]

16. Sheppard, J.P.; Reckziegel, R.B.; Borrass, L.; Chirwa, P.W.; Cuaranhua, C.J.; Hassler, S.K.; Hoffmeister, S.; Kestel, F.; Maier, R.; Mälicke, M.; et al. Agroforestry: An Appropriate and Sustainable Response to a Changing Climate in Southern Africa? Sustain. J. Rec. 2020, 12, 6796. [CrossRef]

17. Cedamon, E.; Nuberg, I.; Pandit, B.H.; Shrestha, K.K. Adaptation factors and futures of agroforestry systems in Nepal. Agrofor. Syst. 2017, 92, 1437-1453. [CrossRef]

18. Oelbermann, M.; Voroney, R.P.; Gordon, A. Carbon sequestration in tropical and temperate agroforestry systems: A review with examples from Costa Rica and southern Canada. Agric. Ecosyst. Environ. 2004, 104, 359-377. [CrossRef]

19. Torralba, M.; Fagerholm, N.; Burgess, P.J.; Moreno, G.; Plieninger, T. Do European agroforestry systems enhance biodiversity and ecosystem services? A meta-analysis. Agric. Ecol. Environ. 2016, 230, 150-161. [CrossRef]

20. Muchane, M.N.; Sileshi, G.W.; Gripenberg, S.; Jonsson, M.; Pumariño, L.; Barrios, E. Agroforestry boosts soil health in the humid and sub-humid tropics: A meta-analysis. Agric. Ecosyst. Environ. 2020, 295, 106899. [CrossRef]

21. Allen, S.C.; Jose, S.; Nair, P.; Brecke, B.J.; Nkedi-Kizza, P.; Ramsey, C.L. Safety-net role of tree roots: Evidence from a pecan (Carya illinoensis K. Koch)-cotton (Gossypium hirsutum L.) alley cropping system in the southern United States. For. Ecol. Manag. 2004, 192, 395-407. [CrossRef]

22. Jose, S. Agroforestry for ecosystem services and environmental benefits: An overview. Agrofor. Syst. 2009, 76, 1-10. [CrossRef]

23. Barrios, E.; Valencia, V.; Jonsson, M.; Brauman, A.; Hairiah, K.; Mortimer, P.E.; Okubo, S. Contribution of trees to the conservation of biodiversity and ecosystem services in agricultural landscapes. Int. J. Biodivers. Sci. Ecosyst. Serv. Manag. 2018, 14, 1-16. [CrossRef]

24. Neupane, R.P.; Sharma, K.R.; Thapa, G.B. Adoption of agroforestry in the hills of Nepal: A logistic regression analysis. Agric. Syst. 2002, 72, 177-196. [CrossRef]

25. Government of Nepal (GoN). Agriculture Development Strategy (ADS), Government of Nepal, Ministry of Agricultural Development; Singhadurbar: Kathmandu, Nepal, 2014. Available online: http:/ /nnfsp.gov.np/PublicationFiles/bf53f040-32cb-4407-a611-d891 935d2e97.pdf (accessed on 1 November 2020).

26. Government of Nepal (GoN). National Forest Policy. Government of Nepal, Ministry of Forest and Environment; Singhadurbar: Kathmandu, Nepal, 2018. Available online: http://mofe.gov.np/downloadfile/Ban\%20Niti_1554873640.pdf?fbclid=IwAR1 kJMxO7q_8P1HV4QnD6puoGEUmFxtaPB2EGBMzdCppjRlBB3D1f1fG-EQ (accessed on 10 November 2020).

27. Government of Nepal (GoN). National Agroforestry Policy, Ministry of Forest and Environment; SinghaDurbar: Kathmandu, Nepal, 2019. Available online: https:/ / www.mofe.gov.np/downloadsdetail/8/2018/36366627/ (accessed on 28 November 2020). 
28. Dhakal, A.; Rai, R.K. Who Adopts Agroforestry in a Subsistence Economy?-Lessons from the Terai of Nepal. Forests 2020, 11, 565. [CrossRef]

29. Dhakal, A.; Cockfield, G.; Maraseni, T.N. Evolution of agroforestry based farming systems: A study of Dhanusha District, Nepal. Agrofor. Syst. 2012, 86, 17-33. [CrossRef]

30. Regmi, B.N. Contribution of agroforestry for rural livelihoods: A case of Dhading District, Nepal. In Proceedings of the International Conference on Rural Livelihoods, Forests and Biodiversity, Bonn, Germany, 19-23 May 2003.

31. Pandit, B.H.; Thapa, G.B. Poverty and Resource Degradation under Different Common Forest Resource Management Systems in the Mountains of Nepal. Soc. Nat. Resour. 2004, 17, 1-16. [CrossRef]

32. Neupane, R.P.; Thapa, G.B. Impact of agroforestry intervention on soil fertility and farm income under the subsistence farming system of the middle hills, Nepal. Agric. Ecosyst. Environ. 2001, 84, 157-167. [CrossRef]

33. Schwab, N.; Schickhoff, U.; Fischer, E. Transition to agroforestry significantly improves soil quality: A case study in the central mid-hills of Nepal. Agric. Ecosyst. Environ. 2015, 205, 57-69. [CrossRef]

34. USDA (United States Department of Agriculture). Fragile Soil Index Interpretation. 2021. Available online: https://www.nrcs usda.gov/wps/PA_NRCSConsumption/download?cid=nrcseprd1298845\&ext=pdf (accessed on 1 March 2021).

35. Singh, B.K. Land Tenure and Conservation in Chure. J. For. Livelihood 2017, 15, 87-102. [CrossRef]

36. Central Department of Environment Science (CDES). Hazard and Vulnerability Analysis of Nepal's Chure Area. Central Department of Environmental Science, Tribhuvan University and Government of Nepal. 2014. Available online: http:/ /202.70.82. 238/cgi-bin/koha/opac-detail.pl?biblionumber=73406 (accessed on 26 November 2020).

37. Ministry of Forest and Soil Conservation (MOFSC). Sustainable Management of Chure: Efforts, Challenges and Potential, Proceedings of the National Seminar on Chure; Ministry of Forest and Soil Conservation, Singhadurbar: Kathmandu, Nepal, 2012; pp. 1-262. Available online: https:/ / chureboard.gov.np/wp-content/uploads/2015/07/National-Seminar-2012_Sustainable-Managementof-Chure_Efforts-Challenges-and-Potential.pdf (accessed on 10 December 2020).

38. Government of Nepal (GoN). Chure Terai Madhesh Conservation or Management Master Plan. (Nepali version). President Chure Terai Madhesh Conservation, Development Board, Kathmandu. 2018. Available online: https://chureboard.gov.np/wpcontent/uploads/2017/07/Master-Plan_Chure_NEPALI_final_29th__Shrawan_2074.pdf (accessed on 3 December 2020).

39. DFRS (Department of Forest Research and Survey). Churia Forests of Nepal. Forest Resource Assessment Nepal Project/Department of Forest Research and Survey; Babarmahal: Kathmandu, Nepal, 2014. Available online: http://frtc.gov.np/old/downloadfile/ CHURE_REPORT_1453193322.pdf (accessed on 10 March 2021).

40. Bhattarai, B.; Bishwokarma, D.; Legras, M. Breaking the Bottleneck: Conflicts Metamorphosis of Chure Landscape Man-agement in Federal Nepal. J. For. Livelihood 2018, 16, 71-86. [CrossRef]

41. Bjärnlid, H. The Slippery Slopes of Forest Governance in the Chure Range. Master's Thesis, Sveriges Lantbruksuniversitet, Uppsala, Sweden, 2016.

42. Bishwokarma, D.; Thing, S.J.; Paudel, N.S. Political Ecology of the Chure Region in Nepal. J. For. Livelihood 2016, 14, 84-96. [CrossRef]

43. Giri, A.; Rana, R.; Devkota, B.; Yadav, B. Intervention Status Mapping of Churia Region: Concept and Scope; Biological Resources Unit, Faculty of Science Nepal Academy of Science and Technology (NAST): Kathmandu, Nepal, 2012.

44. District Development Committee (DDC). Profile of Makawanpur district. District Development Committee. Hetauda, Makawanpur. 2020; (Nepali Version). Available online: http:/ / ddcMakawanpur.gov.np/en/ (accessed on 10 November 2020).

45. Maraseni, T.N.; Shivakoti, G.P.; Cockfield, G.; Apan, A. Nepalese non-timber forest products: An analysis of the equitability of profit distribution across a supply chain to India. Small-Scale For. 2006, 5, 191-206. [CrossRef]

46. Chhetri, M.B.P. Chapter 10: Disaster Management System in Nepal: Time for Policy to Action. In Compendium of Environment Statistics Nepal 2015; ADB Technical Assistance Consultant's Report; Government of Nepal National Planning Commission Secretariat Central Bureau of Statistics; Ramshah Path: Kathmandu, Nepal, 2016.

47. Department of Hydrology and Meteorology (DHM). Study of Climate and Climatic Variation over Nepal; Department of Hydrology and Meteorology: Kathmandu, Nepal, 2015. Available online: http:/ / dhm.gov.np/climate/ (accessed on 26 December 2020).

48. Shrestha, R.P.; Nepal, N. An assessment by subsistence farmers of the risks to food security attributable to climate change in Makawanpur, Nepal. Food Secur. 2016, 8, 415-425. [CrossRef]

49. Ghimire, P.; Bolakhe, S. Agroforestry systems: Biodiversity, carbon stocks and contribution to rural livelihood. J. Agric. For. Univ. 2020, 4, 197.

50. Chetry, M.R.; Silwal, U.K.; Kanel, M.D. Perspective of Farm Gate Agroforestry Product in the Emergency of the Chepangs Community: A Case Study of Mega earthquake of Central Nepal. Int. J. Sci. Res. Manag. 2018, 6, 3.

51. Chhetri, R.; Saxena, S.; Silwal, U.K. Addressing Climate Change and Enriching the Livelihood through Agroforestry: A Case Study of Chepang Community in Raksirang Rural Municipality, Makwanpur. Int. Res. J. Manag. Sociol. Humanit. 2019, 10, 161-177.

52. Khadka, R. Transition from Slash-and-Burn (Khoriya) Farming to Permanent Agroforestry in the Middle Hills of Nepal: An Analysis of Costs, Benefits and Farmers' Adoption. Master's Thesis, Department of Noragric, Norwegian University of Life Sciences, As Municipality, Norway, 2010.

53. Sharma, L.N.; Vetaas, O.R. Does agroforestry conserve trees? A comparison of tree species diversity between farmland and forest in mid-hills of central Himalaya. Biodivers. Conserv. 2015, 24, 2047-2061. [CrossRef] 
54. Kafle, G. An overview of shifting cultivation with reference to Nepal. Int. J. Biodivers. Conserv. 2011, 3, 147-154. [CrossRef]

55. Pandey, B.P.; Kafle, K.R. Landslide hazard assessment using UAV imagery and GIS for road planning and development in Chure area: Sindhuli-Hetauda Section. 2020. Available online: https:/ / www.researchsquare.com/article/rs-72224/v1 (accessed on 18 March 2021).

56. Razali, N.M.; Wah, Y.B. Power comparisons of shapiro-wilk, kolmogorov-smirnov, lilliefors and anderson-darling tests. J. Stat. Model. Anal. 2011, 2, 21-33.

57. Kruskal, W.H.; Wallis, W.A. Use of Ranks in One-Criterion Variance Analysis. J. Am. Stat. Assoc. 1952, 47, 583-621. [CrossRef]

58. R Studio Team. RStudio: Integrated Development for R; R Studio: Boston, MA, USA, 2019; Available online: http://www.rstudio. $\mathrm{com} /$ (accessed on 10 October 2020).

59. Peters, G.J.; Verbon, P.; Green, J. Userfriendlyscience: Quantitative Analysis Made Accessible. 2018. Available online: https: / / userfriendlyscience.com/ (accessed on 10 October 2020).

60. Wilcoxon, F. Individual comparisons by ranking methods. In Breakthroughs in Statistics; Springer: New York, NY, USA, 1992; pp. 196-202.

61. Gill, A.S.; Deb Roy, R. Agroforestry Research Situation in India. In Managing Agriculture for a better Tomorrow: The Indian Experience; Pande, D.C., Ed.; M.D. Publication: Punjab, India, 1998; pp. 385-400.

62. Rapsomanikis, G. The Economic Lives of Smallholder Farmers: An Analysis Based on Household Data from Nine Countries; Food and Agriculture Organization: Rome, Italy, 2015.

63. Eurostat. Eurostat's Concepts and Definitions Database. Glossary: Livestock Unit (LU). 2020. Available online: https:/ / ec.europa. eu/eurostat/statistics-explained/index.php/Glossary:Livestock_unit_(LSU) (accessed on 10 December 2020).

64. Forest Research and Training Center (FRTC). Agroforestry Systems and Practices in Terai and Mid-hills of Nepal; Forest Research and Training Center (FRTC), Ministry of Forests and Environment: Kathmandu, Nepal, 2019. Available online: https:// frtc.gov.np/ downloadfile/finalReport\%20agroforestry_1598333214.pdf (accessed on 1 December 2020).

65. Kiptot, E.; Franzel, S. Gender and Agroforestry in Africa: Are women participating. In Gender and Agroforestry in Africa: Are Women Participating; World Agroforestry Centre: Nairobi, Kenya, 2011; pp. 1-72. [CrossRef]

66. Kassie, G.W. Agroforestry and farm income diversification: Synergy or trade-off? The case of Ethiopia. Environ. Syst. Res. 2017, 6, 8. [CrossRef]

67. Brown, S.; Kennedy, G. A case study of cash cropping in Nepal: Poverty alleviation or inequity? Agric. Hum. Values 2005, 22, 105-116. [CrossRef]

68. Amatya, S.M.; Cedamon, E.; Nuberg, I. Classification of Agroforestry systems. In Agroforestry Systems and Practices in Nepal; Amatya, S.M., Cedamon, E., Nu-berg, I., Eds.; Agriculture and Forestry University (AFU): Rampur, Nepal, 2018 ; pp. $23-33$.

69. Meijer, S.S.; Catacutan, D.; Ajayi, O.C.; Sileshi, G.W.; Nieuwenhuis, M. The role of knowledge, attitudes and perceptions in the uptake of agricultural and agroforestry innovations among smallholder farmers in sub-Saharan Africa. Int. J. Agric. Sustain. 2015, 13, 40-54. [CrossRef]

70. Fischer, A.; Vasseur, L. Smallholder perceptions of agroforestry projects in Panama. Agrofor. Syst. 2002, 54, 103-113. [CrossRef]

71. Roothaert, R.L.; Franzel, S. Farmers' preferences and use of local fodder trees and shrubs in Kenya. Agrofor. Syst. 2001, 52, 239-252. [CrossRef]

72. Roothaert, R.; Franzel, S.; Kiura, M. On-farm evaluation of fodder trees and shrubs preferred by farmers in central kenya. Exp. Agric. 2003, 39, 423-440. [CrossRef]

73. Mekoya, A.; Oosting, S.; Fernandez-Rivera, S.; Van Der Zijpp, A. Multipurpose fodder trees in the Ethiopian highlands: Farmers' preference and relationship of indigenous knowledge of feed value with laboratory indicators. Agric. Syst. 2008, 96, 184-194. [CrossRef]

74. Kunwar, R.M.; Bussmann, R.W. Ficus (Fig) species in Nepal: A review of diversity and indigenous uses. Lyonia $2006,11,85-97$.

75. Snelder, D.J.; Klein, M.; Schuren, S.H.G. Farmers preferences, uncertainties and opportunities in fruit-tree cultivation in Northeast Luzon. Agrofor. Syst. 2007, 71, 1-17. [CrossRef]

76. Central Bureau of Statistics (CBS). Nepal Living Standards Survey 2003-2004, NLSS Second; Central Bureau of Statistics, Na-tional Planning Commission Secretariat, Government of Nepal: Kathmandu, Nepal, 2004. Available online: https://nada.cbs.gov.np/ index.php/catalog/9 (accessed on 10 December 2020).

77. Pokharel, B.K.; Nurse, M. Forests and people's livelihood: Benefiting the poor from community forestry. J. For. Livelihood 2004, 4, 19-29.

78. Maid, M.; Tay, J.; Yahya, H.; Adnan, F.I.; Kodoh, J.; Chiang, L.K. The reliance of the forest community on forest for liveli-hood: A case of Kampung Wawasan Sook, Sabah, Malaysia. Int. J. Agric. For. Plant. 2017, 5, 110-118.

79. Iiyama, M.; Neufeldt, H.; Dobie, P.; Njenga, M.; Ndegwa, G.; Jamnadass, R. The potential of agroforestry in the provision of sustainable woodfuel in sub-Saharan Africa. Curr. Opin. Environ. Sustain. 2014, 6, 138-147. [CrossRef]

80. Murniati, D.; Garrity, P.; Gintings, A.N. The contribution of agroforestry systems to reducing farmers' dependence on the resources of adjacent national parks: A case study from Sumatra, Indonesia. Agrofor. Syst. 2001, 52, 171-183. [CrossRef]

81. Rahman, S.A.; Foli, S.; Pavel, M.A.; Mamun, M.A.; Sunderland, T. Forest, trees and agroforestry: Better livelihoods and ecosystem services from multifunctional landscapes. Int. J. Dev. Sustain. 2015, 4, 479-491.

82. Cedamon, E.D.; Nuberg, I.; Mulia, R.; Lusiana, B.; Subedi, Y.R.; Shrestha, K.K. Contribution of integrated forest-farm system on household food security in the mid-hills of Nepal: Assessment with EnLiFT model. Aust. For. 2019, 82, 32-44. [CrossRef] 
83. Cedamon, E.; Nuberg, I.; Shrestha, K.K. How understanding of rural households' diversity can inform agroforestry and community forestry programs in Nepal. Aust. For. 2017, 80, 153-160. [CrossRef]

84. Government of Nepal (GoN). Presidential Chure Conservation Programme, Yearly Progress Report. (Nepali Version). President Chure Terai Madhesh Conservation Development Board, Kathmandu. 2020. Available online: https://chureboard.gov.np/wpcontent/uploads/2020/10/Annual\%20Progress\%20Report_2076-2077_Chure\%20final\%20print.pdf (accessed on 5 December 2020).

85. Pandit, B.H. Contribution of Community Forestry to Poverty Reduction: A Case Study from Inner Terai, Middle Hills and High Hills of Nepal; Community Based Forest Management in the Himalayas-Phase III; Institute of Forestry: Pokhara, Nepal, 2012.

86. Montagnini, F.; Metzel, R. The Contribution of Agroforestry to Sustainable Development Goal 2: End Hunger, Achieve Food Security and Improved Nutrition, and Promote Sustainable Agriculture. In Advances in Agroforestry; Springer International Publishing: Cham, Switzerland, 2017; pp. 11-45.

87. Waldron, A.; Miller, D.C.; Redding, D.; Mooers, A.; Kuhn, T.S.; Nibbelink, N.; Roberts, J.T.; Tobias, J.A.; Gittleman, J.L. Reductions in global biodiversity loss predicted from conservation spending. Nat. Cell Biol. 2017, 551, 364-367. [CrossRef] [PubMed]

88. International Council for Research in Agroforestry (ICRAF). Agroforestry and ICRAF. 2016. Available online: https://www. worldagroforestry.org/about/agroforestry (accessed on 10 March 2021).

89. Katila, P.; de Jong, W.; Galloway, G.; Pokorny, B.; Pacheco, P. Building on Synergies: Harnessing Community and Smallholder Forestry for Sustainable Development Goals; IUFRO: Vienna, Austria, 2017.

90. De Jong, W.; Pokorny, B.; Katila, P.; Galloway, G.; Pacheco, P. Community Forestry and the Sustainable Development Goals: A Two Way Street. Forests 2018, 9, 331. [CrossRef]

91. Aryal, K.; Laudari, H.K.; Ojha, H.R. To what extent is Nepal's community forestry contributing to the sustainable de-velopment goals? An institutional interaction perspective. Int. J. Sustain. Dev. World Ecol. 2020, 27, 28-39. [CrossRef]

92. Kiyani, P.; Andoh, J.; Lee, Y.; Lee, D.K. Benefits and challenges of agroforestry adoption: A case of Musebeya sector, Nyamagabe District in southern province of Rwanda. For. Sci. Technol. 2017, 13, 174-180. [CrossRef]

93. Amatya, S.M.; Lamsal, P. Private Forests in Nepal: Status and Policy Analysis. J. For. Livelihood 2017, 15, 120-130. [CrossRef] 